\title{
Factors affecting the establishment of early wedding in polewali mandar district
}

\author{
Mandariati, Irfan \\ Stikes Marendeng Majene \\ email: mandariati@gmail.com
}

\begin{abstract}
Abstrak
Pernikahan merupakan hubungan yang sah dari dua orang yang berlainan jenis kelamin. Pernikahan dini merupakan pernikahan yang dilakukan oleh seorang laki-laki dan seorang wanita yang umur keduanya masih dibawah batasan minimum. Tujuan dari penelitian ini untuk mengatahui faktor-faktor apa saja yang mempengaruhi terjadinya pernikahan dini di Desa Ihing Kecamatan Bulo Kabupaten Polewali Mandar . Rancangan penelitian ini menggunakan rancangan observasional analitik dengan pendekatan Crossectional Study .Jumlah sampel 54 orang dipilih secara Consecutive Sampling .Pengambilan sampel dengan menggunakan kuesioner pernikahan dini. Data di analisisd dengan Uji Fither's Exact Test . Hasil penelitian menunjukkan faktor pendidikan sebesar P:0.000, faktor pengetahuan sebesar P:0.024, faktor orang tua sebesar P: 0.000, faktor lingkungan masyarakat/tradisi sebesar P.0.000 dan faktor ekonomi keluarga sebesar P:0.000, dimana semua faktor tersebut diatas memiliki nilai P value lebih rendah dari nilai a sehingga dapat disimpulkan ada pengaruh pendidikan, pengetahuan, orang tua ,lingkungan masyarakat / tradisi dan ekonomi terhadap terjadinya pernikahan didi di Desa Ihing Kecamatan Bulo Kabupaten Polewali Mandar.
\end{abstract}

Kata kunci : Remaja, Pernikahan dini, Faktor pendidikan, Faktor pengetahuan, Faktor orang tua, Faktor lingkungan/trasisi, Faktor ekonomi.

\begin{abstract}
Marriage is the legal relationship of two people of different sexes. Early marriage is a marriage committed by a man and a woman whose age is both still below the minimum limit. The purpose of this study is to find out what factors influence the occurrence of early marriage in Ihing Village, Bulo District, Polewali Mandar Regency. The design of this study used an analytic observational design with a Crossectional Stud approach. a total sample of 54 people were selected by consecutive sampling. Sampling using an early marriage questionnaire. Data were analyzed by the Fither's Exact Test. The results showed that education factors were P: 0.000, knowledge factors were P: 0.0024, parents were $P: 0.000$, community / tradition environmental factors were $p: 0.000$ and family economic factors were: P.0.000, where all the factors above has a $P$ value lower than a value so it can be concluded that there is an influence of education, knowledge, parents, community / tradition and economic environment on the occurrence of marriage in the village of Ihing, Bulo sub-district, Polewali Mandar district.
\end{abstract}

Keywords : Teenagers, Early Marriage, Educational Factors, Knowledge Factors, Parental Factors, Environmental factors / transition, Economic factors. 


\section{Pendahuluan}

Data World Health Organization (WHO) tahun (2012), menunjukkan sekitar 16 juta kelahiran terjadi pada ibu dengan usia 15-19 tahun atau $11 \%$ dari seluruh kelahiran didunia yang mayoritas terjadi di negara sedang berkembang. Di Amerika Latin dan Karibia, $29 \%$ wanita muda menikah saat mereka berusia 18 tahun. Prevalensi kasus pernikahan dini tercatat di Nigeria (80\%), Kongo (74\%), Afganistan (54\%), dan Bangladesh (51\%).

Data United Nations International Children's Emergency Fund (UNICEF) pada tahun 2007 menunjukkan bahwa wanita yang berusia 25-29 tahun yang menikah dibawah usia 18 tahun di Indonesia mencapai 34\%, dan indonesia termasuk dalam lima besar negara-negara yang persentase pernikahan dini tertingggi di dunia. Hasil survey badan pusat statistik menunjukkan pada tahun (2008) terdapat $20 \%$ wanita yang menikah di usia sekitar 15 sampai 9 tahun dan $18 \%$ wanita yang menikah dengan laki-laki dibawah usia 20 tahun (Simamora, 2012). Indonesia juga merupakan negara dengan presentase tertinggi kedua di ASEAN setelah Kamboja. Sebanyak 0,2\% dari 22.000 wanita usia 10-14 tahun sudah menikah. Hasil Riskesdas tahun 2010 menunjukkan 41,9\% perempuan menikah pada umur 15-19 tahun. Persentase perempuan muda berusia 15-19 yang menikah lebih besar jika di bandingkan dengan laki-laki muda berusia 15-19 tahun yaitu $11,7 \%$ perempuan dan 1,6\% laki-laki (Yuswono, 2012).

Faktor yang menyebabkan pernikahan usia muda diantaranya kemauan sendiri karena sudah merasa saling mencintai, faktor dorongan orang tua atau keluarga, juga faktor pendidikan yang begitu rendah yang di sebabkan oleh kondisi ekonomi yang serba pas-pasan (Naibaho, 2013). Pernikahan dini masih marak terjadi secara umum penyebab utamanya sebagai berikut;
Keinginan untuk segera mendapat tambahan anggota keluarga; Tidak adanya pengetahuan mengenai akibat buruk perkawinan terlalu muda, baik bagi mempelai maupun keturunannya; Mengikuti adat secara mentah-mentah.

Tingginya angka pernikahan dini di Indonesia menunjukkan pemberdayaan law enforcement dalam hukum perkawinan masih sangat rendah, apapun alasannya masa muda merupakan waktu untuk membangun emosi, kecerdasan dan fisik dan hal tersebut merupakan syarat dalam menjalani kehidupan yang lebih layak pada masa depan.

Berdasarkarkan latar belakang diatas maka rumusan masalahnya teridentifikasinya faktor-faktor yang mempengaruhi terjadinya pernikahan dini?. Adapun tujuan dari penelitian ini adalah Teridentifikasinya faktor-faktor yang mempengaruhi terjadinya pernikahan dini.

\section{Metode}

Penelitian ini menggunakan metode penelitian obsrvasional analitik dengan pendekatan Crossectional Study. Menurut Notoatmodjo (2010). Crossectional Study adalah suatu penelitian untuk mempelajari suatu dinamika korelasi antara faktor-faktor risiko dengan efek, dan dengan suatu pendekatan, observasi ataupun dengan pengumpulan data pada suatu saat tertentu. Penelitian ini dilaksanakan di Desa Ihing Kecamatan Bulo Kabupaten Polewali Mandar tahun 2017. Besarnya sampel sejumlah 54 responden.

\section{Hasil}

\section{Analisa Univariat}

Hasil penelitian ini diperoleh responden dengan jenis kelamin laki-laki sebanyak 24 orang atau (44.4\%) dan responden dengan jenis kelamin perempuan sebanyak 30 orang (55.6\%). Distribusi responden berdasarkan usia pernikahan, responden dengan usia pernikahan 1 tahun sebanyak 24 orang atau 
(44.4\%), responden dengan usia pernikahan 2 tahun sebanyak 10 orang atau (18.5\%), responden dengan usia pernikahan 3 tahun sebanyak 8 orang atau (14.8\%). Distribusi responden berdasarkan pendidikan orang tua (Ayah), orang tua (ayah) responden dengan pendidikan SD yang tertinggi sebanyak 32 orang atau (59.3\%), orang tua (ayah) responden dengan pendidikan Akademi /Sarjana yang terendah sebanyak 2 orang atau (3.7\%). Distribusi responden berdasarkan pendidikan orang tua (Ibu), orang tua (Ibu) responden dengan pendidikan SD yang tertinggi sebanyak 33 orang atau (61.1\%), orang tua (Ibu) responden dengan pendidikan SMA yang terendah sebanyak 2 orang atau (3.7\%). Distribusi responden berdasarkan pendidikan, responden dengan pendidikan menengah sebanyak 12 oarang atau $(22.2 \%)$ dan responden dengan pendidikan dasar sebanyak 42 orang atau (77.8\%). Distribusi responden berdasarkan umur dengan total responden 54 orang, rata-rata responden yang ada dilokasi penelitian dengan umur 19 Tahun, umur terendah yaitu 17 Tahun dan umur tertinggi adalah 20 Tahun. Distribusi responden berdasarkan pengetahuan, responden dengan pengetahuan baik sebanyak 39 orang atau (72.2\%) dan responden dengan pengetahuan kurang baik sebanyak 15 orang atau (27.8\%). Distribusi responden berdasarkan peran orang tua, responden yang mengikut kepada orang tua sebanyak 33 orang atau $(61.1 \%)$ dan responden yang tidak mengikuti orang tua sebanyak 21 orang atau (38.9\%). Distribusi responden berdasarkan peran lingkungan masyarakat/tradisi, responden yang ikut lingkungan masyarakat/tradisi sebanyak 33 orang atau $(61.1 \%)$ dan responden yang tidak ikut pada lingkungan masyarakat/tradisi sebanyak 21 orang atau $(38.9 \%)$. Distribusi responden berdasarkan peran ekonomi keluarga, responden dengan penghasilan keluarga mencukupi sebanyak 31 orang atau $(57.4 \%)$ dan responden dengan penghasilan keluarga tidak mengcukupi sebanyak 23 orang atau $(42.6 \%)$. distribusi responden berdasarkan remaja melakukan pernikahan dini dengan total responden 54 orang, responden melakukan pernikahan dini sebanyak 42 orang atau $(77.8 \%)$ dan responden yang tidak melakukan pernikahan dini sebanyak 12 orang atau $(22.2 \%)$.

\section{Analisa Bivariat}

Tabel 1

Analisa Pengaruh Pendidikan Terhadap Terjadinya Pernikahan Dini

\begin{tabular}{|c|c|c|c|c|c|c|}
\hline \multirow{3}{*}{$\begin{array}{c}\text { Pendidikan Responden } \\
\text { Menengah }\end{array}$} & \multicolumn{4}{|c|}{ Pernikahan Dini } & \multicolumn{2}{|c|}{ Total } \\
\hline & Ya & $\%$ & Tidak & $\%$ & Total & $\%$ \\
\hline & 0 & 0 & 12 & 22.2 & 12 & 22.2 \\
\hline Dasar & 42 & 77.8 & 0 & 0 & 42 & 77.8 \\
\hline Total & 42 & 77.8 & 12 & 22.2 & 54 & 100.0 \\
\hline \multicolumn{7}{|c|}{$\begin{array}{l}\text { Signifikansi }(\alpha): 0.05 \\
\text { Uji Fisher's Exact Test }: 0.000\end{array}$} \\
\hline
\end{tabular}

Dari tabel diatas pengaruh pendidikan dengan pernikahan dini menunjukkan hasil 42 responden atau $(77.8 \%)$, berpendidikan dasar yang melakukan pernikahan dini, 12 responden atau $(22.2 \%)$ berpendidikan menengah dan tidak melakukan pernikahan dini. Dari hasil analisa pengaruh kedua variabel diatas dengan menggunakan uji Fisher's Exact adalah : 0.000 yang artinya nilai $\mathrm{P}$ value lebih rendah dari nilai $\alpha$ sehingga disimpulkan ada pengaruh yang signifikan antara pendidikan responden terhadap kejadian pernikahan dini di Desa Ihing Kecamatan Bulo Kabupaten Polewali Mandar Tahun 2017 


\section{Analisa Pengaruh Pengetahuan Terhadap Terjadinya Pernikahan Dini}

\begin{tabular}{ccccccc}
\hline \multirow{2}{*}{$\begin{array}{c}\text { Pengetahuan Responden } \\
\text { Baik }\end{array}$} & Ya & \% & Tidak & \% & Total & \% \\
\cline { 2 - 7 } & 27 & 50.0 & 12 & 22.2 & 39 & 72.2 \\
Kurang Baik & 15 & 27.8 & 0 & 0 & 15 & 27.8 \\
Total & 42 & 77.8 & 12 & 22.2 & 54 & 100.0 \\
& $\begin{array}{c}\text { Signifikansi }(\boldsymbol{\alpha}): \mathbf{0 . 0 5} \\
\text { Uji Fisher's Exact Test : } \mathbf{0 . 0 2 4}\end{array}$ & & & \\
\hline
\end{tabular}

Dari tabel diatas pengetahuan dengan pernikahan dini menunjukkan hasil 27 responden atau $(50.0 \%)$ pengetahuan baik yang melakukan pernikahan dini, 12 responden atau (22.2\%) berpengetahuan baik dan tidak melakukan pernikahan dini, dan 15 responden atau (27.8\%) berpengetahuan kurang baik dan melakukan pernikahan dini. Dari hasil analisa pengaruh kedua variabel diatas dengan menggunakan uji Fisher's Exact adalah : 0.024 yang artinya nilai $\mathrm{P}$ value lebih rendah dari nilai $\alpha$ sehingga disimpulkan ada pengaruh yang signifikan antara pengetahuan responden terhadap kejadian pernikahan dini di Desa Ihing Kecamatan Bulo Kabupaten Polewali Mandar Tahun 2017.

\section{Tabel 3}

\section{Analisa Pengaruh Peran Orang Tua Terhadap Terjadinya Pernikahan Dini}

\begin{tabular}{ccccccc}
\hline \multirow{2}{*}{$\begin{array}{c}\text { Peran Orang Tua } \\
\text { Ikut orang tua }\end{array}$} & Ya & \% & Tidak & \% & Total & \% \\
\cline { 2 - 7 } Tidak ikut orang tua & 33 & 61.1 & 0 & 0 & 33 & 61.1 \\
Total & 9 & 16.7 & 12 & 22.2 & 21 & 38.9 \\
\hline & 42 & 77.8 & 12 & 22.2 & 54 & 100.0 \\
& Signifikansi $(\boldsymbol{\alpha}): \mathbf{0 . 0 5}$ & & & \\
\hline
\end{tabular}

Dari tabel diatas peran orang tua dengan pernikahan dini menunjukkan hasil 33 responden atau (61.1\%) melakukan pernikahan dini karena ikut dengan orang tua, 9 responden atau (16.7\%) melakukan pernikahan dini dengan kemauan sendiri/tidak ikut dengan orang tua, dan 12 responden atau $(22.2 \%)$ tidak melakukan pernikahan dini dengan tidak mengikuti orang tua. Dari hasil analisa pengaruh kedua variabel diatas dengan menggunakan uji Fisher's Exact adalah : 0.000 yang artinya nilai $\mathrm{P}$ value lebih rendah dari nilai $\alpha$ sehingga disimpulkan ada pengaruh yang signifikan antara peran orang tua terhadap kejadian pernikahan dini di Desa Ihing Kecamatan Bulo Kabupaten Polewali Mandar Tahun 2017. 


\section{Tabel 4}

Analisa Pengaruh Peran Lingkungan Masyarakat/Tradisi Terhadap Terjadinya Pernikahan Dini

\begin{tabular}{ccccccc}
\hline \multirow{2}{*}{$\begin{array}{c}\text { Ling Masy/Tradisi } \\
\text { Ikut tradisi }\end{array}$} & Ya & $\%$ & Tidak & \% & Total & $\%$ \\
\cline { 2 - 7 } Tidak ikut tradisi & 33 & 61.1 & 0 & 0 & 33 & 61.1 \\
Total & 9 & 16.7 & 12 & 22.2 & 21 & 38.9 \\
& 42 & 77.8 & 12 & 22.2 & 54 & 100.0 \\
& $\begin{array}{c}\text { Signifikansi }(\boldsymbol{\alpha}): 0.05 \\
\text { Uji Fisher's Exact Test : } \mathbf{0 . 0 0 0}\end{array}$ & & & \\
\hline
\end{tabular}

Dari tabel diatas pengaruh lingkungan masyarakat/tradisi terhadap pernikahan dini menunjukkan hasil 33 responden atau $(61.1 \%)$ melakukan pernikahan dini karena ikut dengan tradisi yang ada, 9 responden atau (16.7\%) melakukan pernikahan dini dengan kemauan sendiri/tidak ikut dengan tradisi yang ada, dan 12 responden atau (22.2\%) tidak melakukan pernikahan dini dan tidak mengikuti tradisi yang ada. Dari hasil analisa pengaruh kedua variabel diatas dengan menggunakan uji Fisher's Exact adalah : 0.000 yang artinya nilai $\mathrm{P}$ value lebih rendah dari nilai $\alpha$ maka hasil penelitian ini ada pengaruh yang signifikan antara peran lingkungan masyarakat/tradisi terhadap kejadian pernikahan dini di Desa Ihing Kecamatan Bulo Kabupaten Polewali Mandar Tahun 2017.

Tabel 5

Analisa Pengaruh Peran Ekonomi Keluarga Terhadap Terjadinya Pernikahan Dini

\begin{tabular}{ccccccc}
\hline \multirow{2}{*}{$\begin{array}{c}\text { Ekonomi Keluarga } \\
\text { Mencukupi }\end{array}$} & Ya & \% & Tidak & \% & Total & \% \\
\cline { 2 - 7 } Tidak mencukupi & 19 & 35.2 & 12 & 22.2 & 31 & 57.4 \\
Total & 23 & 42.6 & 0 & 0 & 23 & 42.6 \\
& 42 & 77.8 & 12 & 22.2 & 54 & 100.0 \\
& Signifikansi $(\boldsymbol{\alpha}): 0.05$ & & & \\
& Uji Fisher's Exact Test : $\mathbf{0 . 0 0 0}$ & & & \\
\hline
\end{tabular}

Dari tabel diatas pengaruh ekonomi keluarga terhadap pernikahan dini menunjukkan hasil 19 responden atau (35.2\%) melakukan pernikahan dini dengan ekonomi keluarga yang mencukupi, 23 responden atau $(42.6 \%)$ melakukan pernikahan dini dengan ekonomi keluarga tidak mencukupi, dan 12 responden atau (22.2\%) tidak melakukan pernikahan dini dengan ekonomi yang mencukupi. Dari hasil analisa pengaruh kedua variabel diatas dengan menggunakan uji Fisher's Exact adalah : 0.001 yang artinya nilai $\mathrm{P}$ value lebih rendah dari nilai $\alpha$ maka hasil penelitian ini ada pengaruh yang signifikan antara ekonomi keluarga terhadap kejadian pernikahan dini di Desa Ihing Kecamatan Bulo Kabupaten Polewali Mandar Tahun 2017. 


\section{Pembahasan}

\section{Analisa pengaruh pendidikan terhadap terjadinya pernikahan dini.}

Berdasarkan hasil penelitian pengaruh pendidikan dengan pernikahan dini menunjukkan hasil sebanyak 42 responden atau (77.8\%) berpendidikan dasar yang melakukan pernikahan dini, sebanyak 12 responden atau (22.2\%) berpendidikan menengah dan tidak melakukan pernikahan dini.

Hasil analisa pengaruh kedua variabel diatas dengan menggunakan uji Fisher's Exact adalah : 0.000 yang artinya nilai $P$ value lebih rendah dari nilai $\alpha$ sehingga disimpulkan ada pengaruh yang signifikan antara pendidikan responden terhadap kejadian pernikahan dini.

Hasil penelitian diatas menunjukkan responden dengan pendidikan dasar yang lebih banyak melakukan pernikahan dini. Salah satu faktor terjadinya pernikahan dini lainnya adalah pendidikan remaja dan pendidikan orang tua. Dalam kehidupan seseorang, dalam menyikapi masalah dan membuat keputusan termasuk hal yang lebih kompleks ataupun kematangan psikososialnya sangat dipengaruhi oleh tingkat pendidikan seseorang (Sarwono, 2007).

Tingkat pendidikan maupun pengetahuan anak yang rendah dapat menyebabkan adanya kecenderungan melakukan pernikahan di usia dini (Alfiyah, 2010). Hal ini sejalan dengan penelitian yang dilakukan oleh Nandang \& Jum (2007) yang menunjukkan bahwa remaja muda yang berpendidikan rendah memiliki resiko (ods ratio) 4,259 kali untuk menikah dini daripada remaja muda yang berpendidikan tinggi. Remaja yang memiliki latar belakang pendidikan yang tinggi memiliki resiko lebih kecil untuk menikah dini dibandingkan dengan remaja yang memiliki latar pendidikan rendah. Tingkat pendidikan merupakan salah satu faktor yang mempengaruhi seseorang dalam menyikapi masalah dan membuat keputusan ataupun kematangan psikososialnya.

\section{Analisa pengaruh pengetahuan terhadap terjadinya pernikahan dini}

Pengaruh pengetahuan dengan pernikahan dini menunjukkan hasil sebanyak 27 responden atau (50.0\%) pengetahuan baik yang melakukan pernikahan dini, sebanyak 12 responden atau (22.2\%) berpengetahuan baik dan tidak melakukan pernikahan dini, dan sebanyak 15 responden atau (27.8\%) berpengetahuan kurang baik dan melakukan pernikahan dini.

Dari hasil analisa pengaruh kedua variabel diatas dengan menggunakan uji Fisher's Exact adalah : 0.024 yang artinya nilai $P$ value lebih rendah dari nilai $\alpha$ sehingga disimpulkan ada pengaruh yang signifikan antara pengetahuan responden terhadap kejadian pernikahan dini.

Untuk itu direkomendasikan agar tidak terjadi pernikahan usia dini remaja harus memiliki pengetahuan yang tinggi khususnya tentang kesehatan reproduksi. Untuk peran aktif dari Puskesmas sangat diperlukan dalam peningkatan pengetahuan remaja yang menikah di usia dini tentang risiko pernikahan usia dini dan dapat dilakukan dengan pemberian penyuluhan-penyuluhan tentang penundaan pernikahan hingga remaja putri berusia 20 tahun sehingga risiko pernikahan usia dini dapat dikurangi. Bagi yang telah menikah perlu diberi penerangan tentang keluarga berencana sehingga dapat menunda kehamilan hingga usia 20 tahun. Selain itu Pusat Informasi dan Konseling-Kesehatan Reproduksi Remaja (PIK KRR) perlu diaktifkan disetiap sekolah. 


\section{Analisa pengaruh peran orang tua terhadap terjadinya pernikahan dini}

Pengaruh peran orang tua dengan pernikahan dini menunjukkan hasil sebanyak 33 responden atau $(61.1 \%)$ melakukan pernikahan dini karena ikut dengan orang tua, sebanyak 9 responden atau (16.7\%) melakukan pernikahan dini dengan kemauan sendiri/tidak ikut dengan orang tua, dan sebanyak 12 responden atau (22.2\%) tidak melakukan pernikahan dini dengan tidak mengikuti orang tua.

Hasil analisa pengaruh kedua variabel diatas dengan menggunakan uji Fisher's Exact adalah : 0.000 yang artinya nilai $P$ value lebih rendah dari nilai $\alpha$ sehingga disimpulkan ada pengaruh yang signifikan antara peran orang tua terhadap kejadian pernikahan dini.

Peran orang tua terhadap kelangsungan pernikahan dini pada dasarnya tidak terlepas dari tingkat pengetahuan orang tua yang dihubungkan pula dengan tingkat pendidikan orang tua. Selain itu, tingkat pendidikan keluarga ini akan mempengaruhi pemahaman keluarga tentang kehidupan berkeluarga yang lebih baik. Orang tua yang memiliki pemahaman rendah terhadap berkeluarga akan memandang bahwa dalam kehidupan berkeluarga akan tercipta suatu hubungan silaturahmi yang baik, sehingga pernikahan yang semakin cepat maka solusi utama bagi orang tua.

Remaja yang memiliki latar belakang orang tua berpendidikan rendah maka memiliki resiko lebih besar untuk menikah dini daripada remaja yang memiliki latar belakang orang tua berpendidikan tinggi. Salah satu faktor yang dapat mempengaruhi keputusan pihak orang tua terhadap anaknya salah satunya yang menonjol adalah faktor pendidikan keluarga.
Peran orang tua sangat penting dalam membuat keputusan menikah di usia muda dimana keputusan untuk menikah di usia muda merupakan keputusan yang terkait dengan latar belakang relasi yang terbangun antara orang tua dan anak dengan lingkungan pertemanannya.

\section{Analisa pengaruh peran lingkungan masyarakat/ tradisi terhadap terjadinya pernikahan dini}

Pengaruh lingkungan masyarakat/tradisi terhadap pernikahan dini menunjukkan hasil $61.1 \%$ atau 33 responden melakukan pernikahan dini karena ikut dengan tradisi yang ada, $16.7 \%$ atau 9 responden melakukan pernikahan dini dengan kemauan sendiri/tidak ikut dengan tradisi yang ada, dan $22.2 \%$ atau 12 responden tidak melakukan pernikahan dini dan tidak mengikuti tradisi yang ada.

Dari hasil analisa pengaruh kedua variabel diatas dengan menggunakan uji Fisher's Exact adalah : 0.000 yang artinya nilai $\mathrm{P}$ value lebih rendah dari nilai $\alpha$ maka hasil penelitian ini ada pengaruh yang signifikan antara peran lingkungan masyarakat/tradisi terhadap kejadian pernikahan dini.

Pernikahan dini di lingkungan remaja cenderung berdampak negatif baik dari segi sosial ekonomi, mental/psikologis, fisik, terutama bagi kesehatan reproduksi sang remaja tersebut (Nad, 2014). Dampak dari pernikahan usia dini kesehatan reproduksi salah satunya yaitu perempuan usia 15-19 tahun memiliki kemungkinan dua kali lebih besar meninggal saat melahirkan dibandingkan yang berusia 20-25 tahun, sedangkan usia di bawah 15 tahun kemungkinan meninggal bisa lima kali. Perempuan muda yang sedang hamil, berdasarkan penelitian akan mengalami beberapa hal, seperti akan mengalami pendarahan, keguguran, dan persalinan yang lama atau sulit (Nad,2014). Oleh karena itu, 
pernikahan dini memiliki banyak dampak negatif yang sangat penting untuk diketahui baik oleh remaja maupun orang tua.

\section{Analisa pengaruh peran ekonomi terhadap terjadinya pernikahan dini}

Pengaruh status ekonomi terhadap pernikahan dini menunjukkan hasil $35.2 \%$ atau 19 responden melakukan pernikahan dini dengan ekonomi keluarga yang mencukupi, $42.6 \%$ atau 23 responden melakukan pernikahan dini dengan ekonomi keluarga tidak mencukupi, dan $22.2 \%$ atau 12 responden tidak melakukan pernikahan dini dengan ekonomi yang mencukupi.

Dari hasil analisa pengaruh kedua variabel diatas dengan menggunakan uji Fisher's Exact adalah : 0.001 yang artinya nilai $P$ value lebih rendah dari nilai $\alpha$ maka hasil penelitian ini ada pengaruh yang signifikan antara ekonomi keluarga terhadap kejadian pernikahan dini

Faktor yang berhubungan dengan pernikahan dini adalah pekerjaan pelaku pernikahan dini. Pekerjaan dapat mengukur status sosial ekonomi serta masalah kesehatan dan kondisi tempat seseorang bekerja (Guttmacher dalam Yunita, 2014). Hal ini sejalan dengan penelitian yang dilakukan oleh Zai (2010) yang mengungkapkan bahwa terdapat hubungan antara pekerjaan responden dengan kejadian pernikahan dini. Pekerjaan seseorang dapat mencerminkan pendapatan, status sosial, pendidikan dan masalah kesehatan bagi orang itu sendiri.

\section{Kesimpulan}

1. Ada pengaruh antara pendidikan responden terhadap kejadian pernikahan dini.

2. Ada pengaruh antara pengetahuan responden terhadap kejadian pernikahan dini.
3. Ada pengaruh antara peran orang tua terhadap kejadian pernikahan dini.

4. Ada pengaruh antara peran lingkungan masyarakat/tradisi terhadap kejadian pernikahan dini.

5. Ada pengaruh antara ekonomi keluarga terhadap kejadian pernikahan dini.

\section{Saran}

Diharapkan dari hasil penelitian ini dapat dijadikan acuan khususnya bagi pelayanan kesehatan untuk lebih meningkatkan pendidikan kesehatan bagi remaja dan orang tuanya tentang bahayanya melakukan pernikahan dini bagi kesehatan maupun masa depan bagi remaja itu sendiri. Selain itu diharapkan bagi peneliti selanjutnya agar melakukan penelitian terkait dengan faktorfaktor yang mempengaruhi terjadinya pernikahan dini dengan menggunakan metode yang lain.

\section{Daftar Pustaka}

Alfiah.(2010). Sebab - sebab Pernikahan Dini. Jakarta, EGC

AlGhifari,A. (2002) Pernikahan Dini Dilema Generasi Extravaganza. Mujahid Press. Bandung.

Ahmad. (2010) Pencegahan Pernikahan Usia Dini .Diakses pada tanggal 16 Juli $2017 \quad$ http;// dutasmart.wordpress.com /pencegahan pernikahan-dini/.

Astuty,R. (2011) Peningkatan kasus perceraian .Diakses pada tanggal $16 \mathrm{Juli}$ $2017 \mathrm{http} ; / /$ nasional . kompas .com /read/2011/02/25/09523453/Angka perceraian .di Belitar,Naik Drastis

Betty.(2013) .Hubungan Pernikahan Dini Dengan Perceraian (Studi kasus Pengadilan Agama Bengkulu).Diakses pada tanggal 04 September 2017; http;adab,radenfatah.ac.id/hubunga n \%20 pernikahan \%20dini\%20 dengan $\% 20$ perceraian pdf. 
BKKBN, (2012). Kebijakan Teknis Program Perlindungan Hak-hak Reproduksi.Jakarta

Handayani, E.Y .(2014) Faktor-faktor Yang Berhubungan Dengan Pernikahan Usia Dini Pada Remaja Putri di Kecamatan Tambusai Utara Kabupaten Rokan Hulu.Diakses pada tanggal17Juli2017http;//www,google.co $\mathrm{m} / \mathrm{url}$ ?Sa $=\mathrm{t} \& \mathrm{rct}=\mathrm{j} \& \mathrm{q}=\mathrm{esrc}=\mathrm{s} \&$ source $=\mathrm{we}$ $\mathrm{b} \& \mathrm{~cd}=1 \& \mathrm{cad}=\mathrm{rja} \&$ uacc $=8 \&$ vede $=\mathrm{oahU}$ KEwiR4nts7PVAhX,Jro8KHRAhbECQF gg1MAA\&url=http $\% 3 \mathrm{~A} \% 2 \mathrm{~F} \% 2 \mathrm{Fejourna}$ l.upp.ac.id\%2Findex.php\%2Fakbd\%2Far teccel\%2Fdownload\%2F812\&usg=AFQJ CF4MTRF8XdR31 flxp4r8XvUKTIKdw.

Jannah,F. (2012). Pernikahan Dini Dan Implikasinya Terhadap Kehidupan Keluarga Pada Masyarakat Madura(Perspektif Hukum dan Gender). Egalita.Vol 7 No 1 .Diakses 10 Juli 201\%20impli7http;//repositoryuinmalang .ac.id/662/1/Sumbulah\%20and\%20Janna $\mathrm{h} \% 20-\%$ .202012\%20\%20Pernikahan\%20dini $\% 20$ dan\%20implikasinya\%20terhadap $\% 20$ kehidupan .pdf.

Juspin.L.Ridwan T, Zulkifli A, Studi Kaus Kebiasaan Pernikahan Usia Dini Pada Masyarakat Kecamatan Sanggangi Kabupaten Tanah Toraja.Makassar:Jurnal MKMI. Vol 5 No 4 Oktober 2009, hal 89-94.Diakses pada tanggal 10 September 2017 http;//repository.unhas .ac.id/bitstream/handle/123456789/2971/ MKMI\%20vol1\%205\%20pernikahan\%2 Ousia\%20dini.pdf?sequence $=2$

Landung DKK (2009) Setudi Kasus Kebiasaan Pernikahan Usia Dini Pada Masyarakat Kecamatan Sanggangi Kabupaten Tanah Toraja .Jurnal IIIKi,5(4).89-94.Makassar:Fakultas

Kesehatan Masyarakat Unifersitas Hasanuddin 10 Juli 2017 http;// repository.unhas.ac.id/bitstream/handle/1 23456789/2971/MKMI\%20vol1\%205\%2 0pernikahan\%20usia\%20dini.pdf?sequen $\mathrm{ce}=2$

Luthfiyah,D.(2008)Pernikahan Dini Pada Kalangan Remaja (15-19 tahun) .Diakses 14 Juli 2017http;//nyna0626.blogspot.co.id/2008/ 10.pernikahan dini-padaa-kangan-remaja$15 \mathrm{html}$

Lembaga Demografi Fakultas Ekonomi Universitas Indonesia (2007)Pertumbuhan Penduduk Kebijakan Keluarga Berencana Dan Bonus Demografi. Laporaan Akhir, Jakarta

Nad.(2014).Beragam Efek Buruk Pernikahan Dini .Diakses 10 September 2017; http/ /www beritasatu.com/gayahidup/177423-beragam-efek-burukpernikahan-dini.htmt

Naibaho.E.(2013)Pengaruh Sosial Budaya Terhadap Pemenuhan Hak-Hak Reproduksi Wanita Pada Pasangan Usia Subur di Rumah Sakit Tingkat II DAM I/BB di Kota Medan Tahun 2012.Tesis Program Studi Magister Ilmu Kesehatan Masyarakat Program Pasca Serjana Universsitas Sumatra Utara .Diakse 14 Juli 2017http;/repositiry.usu.ac.id/handl/ $123456789 / 34692$.

Nandang M. jun.R (20070.Faktor-faktor yang berhubungan dengan usia menikah muda pada wanita dewasa muda di kelurahan mekar sari kota Bandung.Jurnal kesehatan kartika STIKES.A.yani .Diakses 14 juli 2017 http;//stikesayani.ac.id/publikasi/e-

journal/files/ 2009 /200908 /200908007.pdf

Nurhayati L .Wardiningrum D.,(2013).Komunikasi Keluarga Dalam Pengambilan Keputusan Perkawinan.Jakarta:Universitas Al Ashar Indonesia.

Nurhasanah.U \& Susetya (2015). Perkawinan usia muda dan perceraian dikampung Kotabaru Kecamataan Pandangratu Kabupaten Lampung Tengah.Jurnal.Sosiologi vol.15.No.1:34- 
41.Diakses pada tanggal 04 September 2017:http://digilib.uin-

suka.id/19426/2/11710134-bab i-iv-atauv-daftar-pustaka.pdf.

Nursalam.(2011).Konsep dan penerapan metodelogi penelitian ilmu keperawatan. Jakarta:Salemba Merdika.

Rani.Fitrianingsih.(2015).Faktor-Faktor

Penyebab Pernikahan Usia Muda Perempuan Desa Sumberdanti Kecamatan Sukowono Kabupaten Jember Diakses pada tanggal 1y6 Jul 2017 http;//repository.unei.ac.id/bitstream/hand le/123456789/7333383/100210301056RANI\%20FITRIANINGSIH-141.pdf?sequence $=1$

Rahmah. N. (2009) .Kontroversi Pernikahan Di Bawah Umur Di Indonesia . Jakarta

Suhardi. (2012). Pernikahan Dini, Perceraian Dan Pernikahan Ulang : Sebuah Telah dalam perspektif Sosiologi. Komunitas 4 (2): 168:177.Jawa Tengah ; Diakses pada $\begin{array}{llll}\text { tanggal } & 16 & \text { Juli } & 2017\end{array}$ http;//journal.unnes.ac.idnyu/indekx .php/komunitas.

Yunita, A. (2014). Faktor-faktor yang berhubungan dengan kejadian pernikahan usia muda pada remaja putri di desa pengrejo Kabupaten Wonosobo:STIKES Ngudi Waluyo 